\title{
Direct expression of active spinach glycolate oxidase in Escherichia coli
}

\author{
Peter Macheroux ${ }^{a}$, Scott B. Mulrooney ${ }^{b}$, Charles H. Williams, Jr. ${ }^{b}$ \\ and Vincent Massey ${ }^{a}$ \\ " Department of Biological Chemistry, Unicersity of Michigan Medical School, Ann Arbor, MI (USA) \\ and ${ }^{h}$ Department of Veterans Affairs Medical Center, Ann Arbor, MI (USA)
}

(Received 24 January 1992)

(Revised manuscript received 28 April 1992)

Key words: Glycolate oxidase; Enzyme expression; Expression comparison; (E. coli)

Spinach glycolate oxidase (GAO) was expressed in Escherichia coli using the T7 RNA polymerase promotor. The enzyme accounts for approx. $1 \%$ of the soluble protein fraction and is expressed as a soluble and active enzyme. Comparison with GAO expressed in Saccharomyces cerevisiae (Macheroux, P., Massey, V., Thiele, D.J. and Volokita, M. (1991) Biochemistry 30, 4612-4619) showed that the GAO expressed in E. coli has identical physico-chemical features to the wild-type enzyme, but is expressed at a level approx. 15-fold higher than in the yeast system.

\section{Introduction}

Spinach glycolate oxidase (GAO) has been the subject of intensive studies which led to the determination of the active site structure [1]. Recently, the spinach glycolate oxidase gene was cloned by Volokita and Somerville [2]. Therefore, spinach glycolate oxidase became a prime candidate among flavoprotein oxidases to investigate the role of the amino acid residues in the active site by using site-directed mutagenesis. Unfortunately, glycolate oxidase expressed as a $\beta$-galactosidase fusion protein was completely insoluble and hence inactive (Volokita and Somerville, personal communication). Marston [3] has recently noted in a review that most eucaryotic polypeptides expressed as fusion proteins in Escherichia coli are insoluble. However, attempts to express active glycolate oxidase directly, under the control of the heat-inducible $\lambda \mathrm{PL}$ promotor, also gave rise to an inactive protein which was found to have a lower molecular weight (Söderlind and Lindqvist, personal communication). In both cases the protein was expressed in large quantities $(\sim 20 \mathrm{mg} / \mathrm{l}$ of cell culture).

Correspondence to: (present address) P. Macheroux, Universität Konstanz, Fakultät für Biologie, Postfach 5560, W-7750 Konstanz, Germany.

Abbreviations: GAO, spinach glycolate oxidase; IPTG, isopropyl- $\beta$ D-thiogalactopyranoside; PMSF, phenylmethanesulfonyl fluoride; FMN, flavin mononucleotide; SDS, sodium dodecylsulfate.
Recently, we reported the expression of active glycolate oxidase in Saccharomyces cerevisiae [4]. This expression is under the control of the constitutive $\mathrm{ADH}_{1}$ promotor and the yield of the target protein is very low, amounting to approx. $0.07 \%$ of the total soluble protein fraction [4]. Although this was sufficient to characterize the basic properties of the enzyme it was clearly desirable to obtain larger quantities. Moreover, it was observed that the yield with some genetically engineered mutants was drastically reduced and we were unable to isolate enough material to characterize their physico-chemical properties.

Heterologous proteins have been successfully expressed in E. coli using the T7 RNA polymerase expression system developed by Studier and his coworkers [5]. Therefore, we cloned the gene of spinach glycolate oxidase into such an expression system. With this system we achieved overexpression of soluble, active glycolate oxidase in $E$. coli which will enable us to study more readily active site mutants of the protein. In this paper we describe the construction of the new recombinant plasmid, demonstrate the identity of the enzyme expressed in $E$. coli with that from yeast and characterize the conditions under which maximal yields of enzyme are obtained.

\section{Materials and Methods}

Materials

Restriction enzymes. NcoI and Pst I were from Bethesda Research Laboratories, Gaithersburg, MD 
(BRL). BamHI and EcoRI were from Toyobo, Japan and $B c l$ I was from Boehringer, Indianapolis, IN.

Antibiotics. Ampicillin, kanamycin and chloramphenicol were from Sigma, St. Louis, MO.

Growth media. Yeast extract and bacto-tryptone were from Difco, Detroit, MI. Glycerol (NB grade) was from Boehringer.

Other enzymes. T4 DNA ligase was from BRL and horseradish peroxidase was from Sigma. Sequenase was obtained from US Biochemicals, Cleveland, $\mathrm{OH}$.

Chemicals. $o$-Dianisidine, flavin mononucleotide (FMN), isopropyl- $\beta$-D-thiogalactopyranoside (IPTG) and phenylmethanesulfonyl fluoride (PMSF) were from Sigma. Glycolic acid was from Aldrich, St. Louis, MO.

\section{Methods}

Construction of the expression plasmid. All restriction enzyme digestions, ligations and other common DNA manipulations, unless otherwise stated, were performed by standard procedures [6]. The cDNA clone of glycolate oxidase (GAO) contained in plasmid pGAO [4] was recovered by digestion with EcoRI and subsequent isolation of the small $1400 \mathrm{bp}$ fragment by agarose electrophoresis (1\%) and electroblotting on DEAE cellulose (Schleicher \& Schüll, NA 45). The GAO gene was then cloned into the EcoRI site of plasmid (+) pBluescript (Stratagene, La Jolla, CA) and the orientation of the inserted gene was checked by digestion with Pst I. In order to clone the GAO gene into the expression plasmid pET-3d it was necessary to introduce $N \mathrm{CoI}$ and $B c l$ I restriction sites at the $5^{\prime}$ and $3^{\prime}$ ends, respectively. The two oligonucleotides used for the directed mutagenesis are shown in Fig. 1. The mutagenesis was performed with the Amersham mutagenesis system, version 2 (Amersham Corporation, Arlington Heights, IL) and all steps were carried out as described in the protocol. The two silent mutations were introduced in two consecutive mutagenesis experiments. The sequence of the entire gene was then verified by single-strand dideoxy sequencing using the Sequenase sequencing system (USB, Cleveland, $\mathrm{OH}$ ). The plasmid, isolated from E. coli strain GM119 [7], was then digested with $B c l$ I and partially with $\mathrm{Nco}$ I; the $1150 \mathrm{bp}$ fragment, containing the full length sequence of the GAO gene, was isolated as described above. Plasmid pET-3d was digested with NcoI and $B a m \mathrm{HI}$ and the large fragment was isolated and purified in the same way. The silently mutated GAO gene was now inserted into the $N c o I-B a m H I$ restriction fragment of the expression vector using T4 DNA lig-
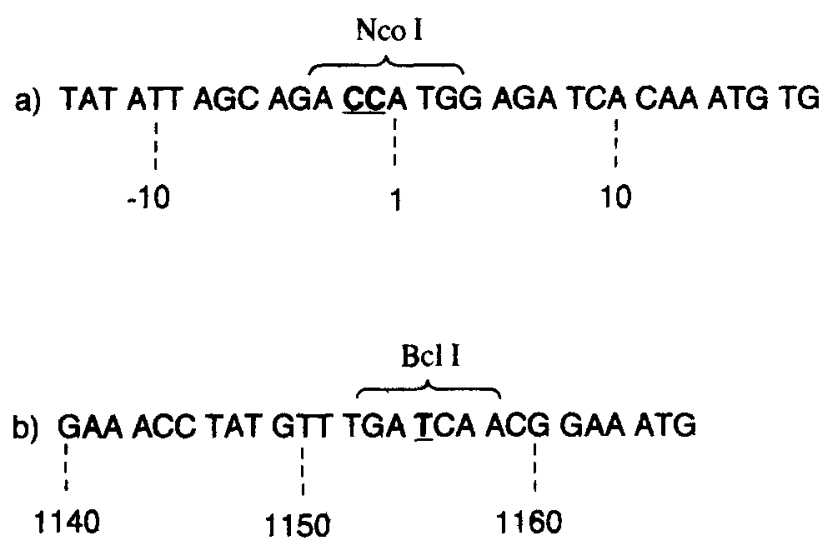

Fig. 1. The two oligonucleotides for introducing $N c o I$ and $B c / l$ restriction sites, are shown, respectively. The nucleotides which caused the mutation of the original sequence are boldfaced and underlined. The position of the nucleotides in the sequence of the glycolate oxidase gene are given below the oligonucleotide sequence. The NcoI site was introduced at position -1 , just upstream of the ATG start codon. The $B c l$ I site was created 42 nucleotides downstream from the termination codon.

ase. The strategy used to clone the GAO gene into the T7 RNA polymerase expression vector is outlined in Fig. 2.

Microbiological manipulations. TB-medium [6] was used for all bacterial cultures. Where required ampicillin $(100 \mu \mathrm{g} / \mathrm{ml})$ and chloramphenicol $(50 \mu \mathrm{g} / \mathrm{ml})$ were added. Plasmid pBluescript was propagated in $E$. coli strain XL1:blue [8] or strain GM119. Strain HMS174 was used to propagate plasmid pPM1 and strain BL21 (DE3)/pLysS [5] was used for expression of the spinach glycolate oxidase. All necessary transformations were carried out with the calcium chloride method as described in the literature [6]. Single-strand DNA for sequencing and the mutagenesis experiments was produced by infecting XL1:blue transformants with the helper phage $\mathrm{M} 13 \mathrm{KO} 7$ using standard procedures [6].

Purification of $G A O$ derived from E. coli. Cells from a 11 growth were harvested by centrifugation at 20000 $\times g$ for $20 \mathrm{~min}$ and the pellet was resuspended in 30 $\mathrm{ml} 0.1 \mathrm{M}$ Tris buffer ( $\mathrm{pH} 8)$, containing $1 \mathrm{mM}$ EDTA, $0.5 \mathrm{mM}$ FMN and $0.5 \mathrm{mM}$ PMSF. The cells were immediately frozen and stored at $-20^{\circ} \mathrm{C}$ for at least 15 $\mathrm{h}$ and then thawed. Due to the presence of lysozyme in the cells, freezing and thawing was an efficient method of achieving complete lysis. The viscosity of the resulting lysate, owing to the presence of uncleaved DNA, was reduced by adding DNase to a final concentration of $3 \mu \mathrm{g} / \mathrm{ml}$ and incubated for $60 \mathrm{~min}$ at $25^{\circ} \mathrm{C}$. This

Fig. 2. Strategy for cloning the gene of glycolate oxidase into expression plasmid pET-3d. The steps are described in detail in the text. Abbreviations used in this figure are as follows: $P, T 7$ promotor; T, T7 terminator; GAO, the gene of spinach glycolate oxidase; $A_{p}$, ampicillin resistance; $\mathrm{Tc}$, tetracyclin resistance; $\mathrm{ADHI}_{\mathrm{P}}$, alcohol dehydrogenase promotor; $\mathrm{CYC}_{\mathrm{T}}$, termination signal from the yeast iso-1-cytochrome $c$ gene; TRP1, tryptophane synthetase gene. 


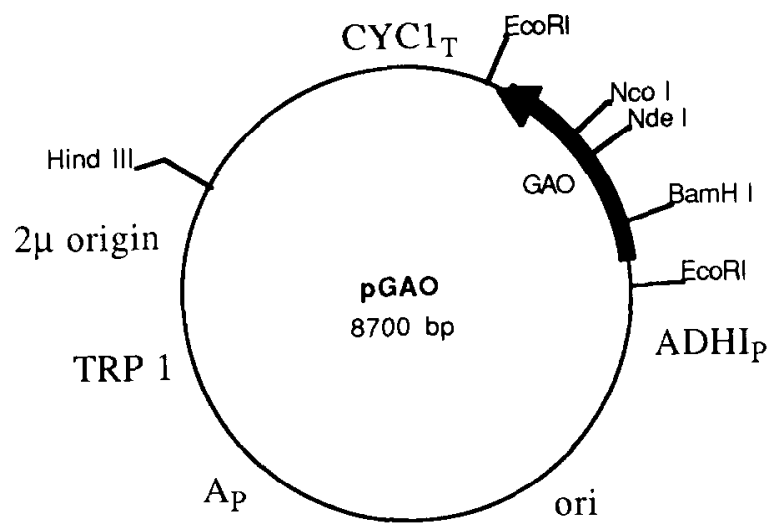

1) EcoR I fragment cloned into pBluescript

2) Introduction of Nco I ( -1 bp upstream) and Bcl I ( +45 bp downstream) by sitedirected mutagenesis
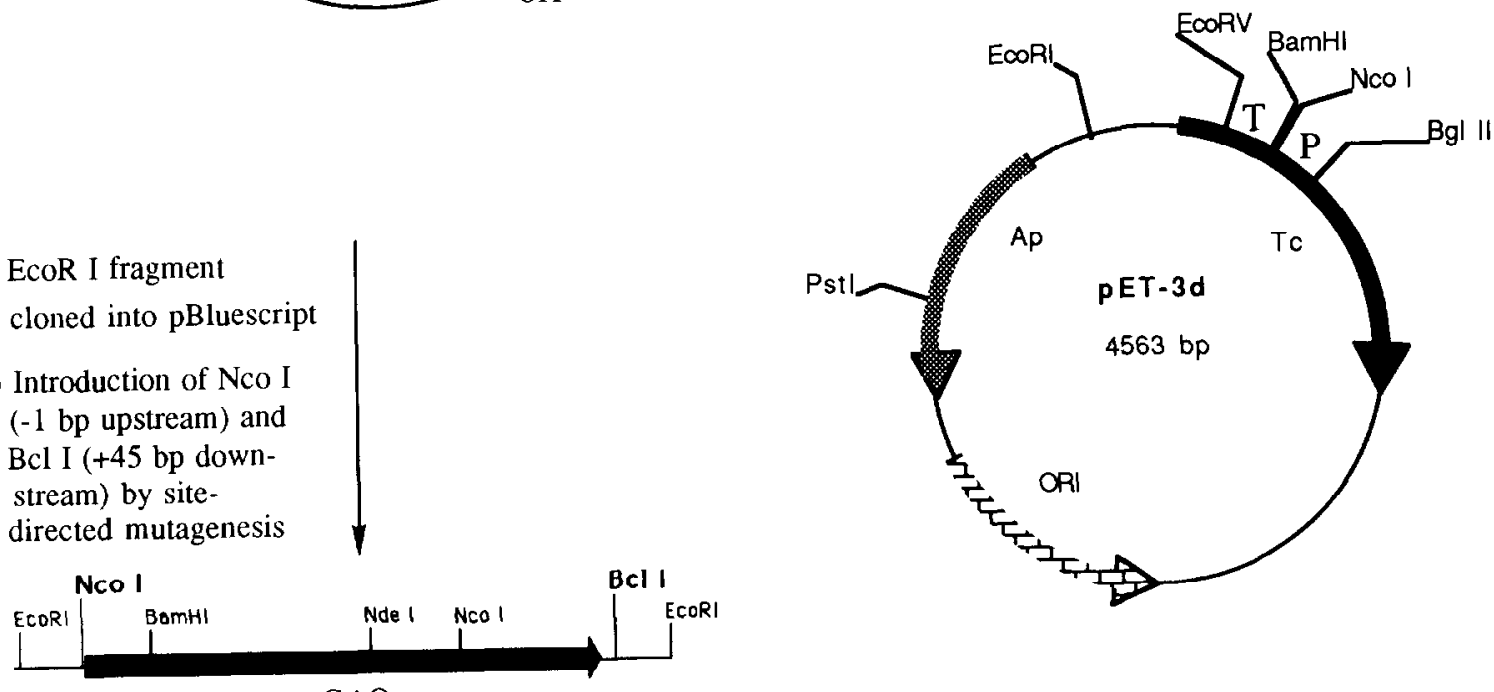

1) Digestion with $\mathrm{Bcl} I$ and partial digestion with Nco I

2) isolate $1150 \mathrm{bp}$ fragment

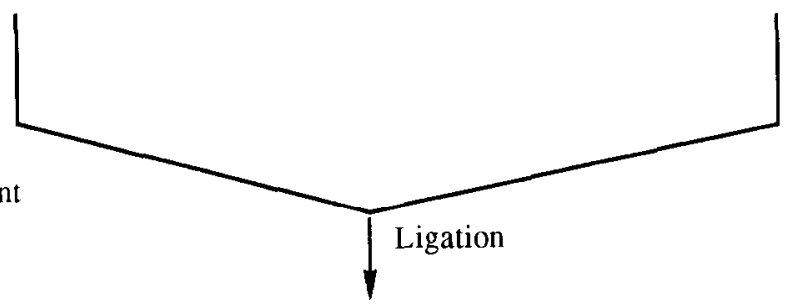

Digestion with BamH I and Nco I

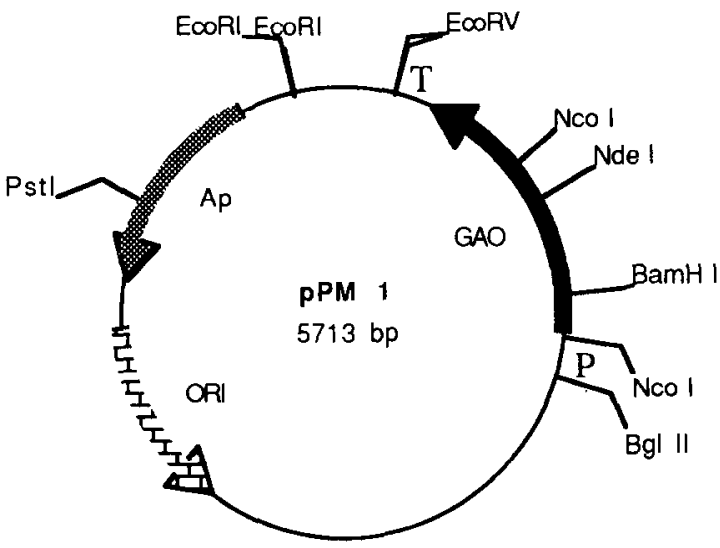


TABLE I

Purification of spinach glycolate oxidase expressed in Escherichia coli

\begin{tabular}{lllllcr}
\hline $\begin{array}{l}\text { Purification } \\
\text { step }\end{array}$ & $\begin{array}{l}\text { Volume } \\
(\mathrm{ml})\end{array}$ & $\begin{array}{l}\text { Protein content } \\
(\mathrm{mg} / \mathrm{ml})\end{array}$ & $\begin{array}{l}\text { Activity } \\
(\Delta \mathrm{OD} / \mathrm{min})\end{array}$ & $\begin{array}{l}\text { Specific activity } \\
\left(\Delta / \mathrm{min} \times \mathrm{OD}_{2 \times 0}\right)\end{array}$ & $\begin{array}{l}\text { Yield } \\
(\%)\end{array}$ & $\begin{array}{l}\text { Purification } \\
(n \text {-fold })\end{array}$ \\
\hline $\begin{array}{l}\text { Crude extract } \\
\text { Dialysis }\end{array}$ & 35 & 27.5 & 0.18 & 0.007 & 100 & 1 \\
Hydroxyapatite (pool) & 40 & 24 & 0.15 & 0.00625 & 95 & 0.9 \\
Q-sepharose (pool) & 18 & 3.36 & 0.234 & 0.069 & 67 & 10 \\
\hline
\end{tabular}

"Crude extract was prepared from $14 \mathrm{~g}$ of cells. Expression of GAO was induced at $\mathrm{OD}_{6(1)}=1$ and cells were harvested after $4 \mathrm{~h}$.

"Protein concentration was estimated by assuming that an $\mathrm{OD}_{2 \times(1)}$ of 1 equals $1 \mathrm{mg} / \mathrm{ml}$ protein.

- Activity was determined by using the enzyme-coupled assay described in Materials and Methods.

crude extract was centrifuged at $40000 \times g$ for $30 \mathrm{~min}$ and the supernatant decanted and dialyzed against three changes of $1 \perp 5 \mathrm{mM}$ Tris buffer ( $\mathrm{pH} 8.3$ ), containing $1 \mathrm{mM}$ EDTA. The enzyme was then purified on hydroxyapatite and Q-sepharose as described previously [4]. Details of a typical preparation are summarized in Table I.

Enzyme assay. Glycolate oxidase activity was measured in an enzyme-coupled assay using horseradish peroxidase and $o$-dianisidine to utilize hydrogen peroxide generated during oxidation of glycolate. A typical assay mixture contained $10 \mu \mathrm{l}$ of horseradish peroxidase $(1 \mathrm{mg} / \mathrm{ml}), 50 \mu 1$ of $o$-dianisidine solution $(8 \mathrm{mM}$, $20 \%$ Triton X-100), $10 \mu \mathrm{l}$ of $1 \mathrm{M}$ sodium glycolate, and $930 \mu 1$ of $0.1 \mathrm{M}$ potassium phosphate buffer $(\mathrm{pH} 8.3$ ). The reaction was started by adding $10 \mu 1$ of the glycolate oxidase sample. Formation of the $o$-dianisidine radical cation $\left(\varepsilon_{440}=11600 \mathrm{M}^{-1} \mathrm{~cm}^{-1}\right)$, which reflects the catalytic activity of glycolate oxidase, was monitored at $440 \mathrm{~nm}$ and at $25^{\circ} \mathrm{C}$.

Amino acid sequence determination. N-terminal sequence determination was performed with an Applied Biosystems 470 gas-phase sequenator, and carried out by the Protein Sequence Facility, University of Michigan.

\section{Results and Discussion}

Expression of spinach glycolate oxidase in E. coli

Spinach glycolate oxidase is expressed in $E$. coli in a soluble and active form using the T7 DNA polymerase directed expression system described by Studier and coworkers [5]. Upon induction of the expression system with IPTG the enzyme could be detected on SDS-polyacrylamide gel electrophoresis (Fig. 3) as well as by its enzymatic activity. Since expression of heterologous proteins in $E$. coli frequently yields insoluble protein (inclusion bodies) (see, for example, Ref. 9) we compared the proteins of the supernatant with the proteins of the pellet by SDS-gel electrophoresis (data not shown). From this comparison it was obvious that most if not all of the expressed GAO was contained in the supernatant, i.e., it is soluble.

Identity of spinach glycolate oxidase from different expression systems

GAO expressed in E. coli could be purified using the same procedure that was described for spinach GAO expressed in Saccharomyces cerevisiae [4]. In both chromatographic steps the enzyme expressed in $E$. coli exhibited the same binding properties as the

TABLE II

Comparison of $K_{m}$-lalues and specific actic ities of glycolate oxidases isolated from various sources

Values were taken from the following publications: 10, Zelitch and Ochao, 1953; 11, Frigerio and Harbury, 1958; 12, Kerr and Groves, 1975; 13, Nishimura et al., 1983.

\begin{tabular}{|c|c|c|c|c|c|}
\hline & $\begin{array}{l}\text { Spinach } \\
\text { GAO }\end{array}$ & $\begin{array}{l}\text { Yeast-derived } \\
\text { spinach GAO }\end{array}$ & $\begin{array}{l}\text { E. coli-derived } \\
\text { spinach GAO }\end{array}$ & $\begin{array}{l}\text { Pea leaves } \\
\text { GAO }\end{array}$ & $\begin{array}{l}\text { Pumpkin cotyledon } \\
\text { GAO }\end{array}$ \\
\hline $\begin{array}{l}K_{\mathrm{m}} \text { for glycolate }{ }^{\mathrm{a}} \\
(\mathrm{mM})\end{array}$ & $0.38\left(30^{\circ} \mathrm{C}\right)^{10}$ & $0.25\left(25^{\circ} \mathrm{C}\right)$ & $0.2\left(25^{\circ} \mathrm{C}\right)$ & $0.25\left(30^{\circ} \mathrm{C}\right)^{12}$ & $0.33\left(35^{\circ} \mathrm{C}\right)^{1.3}$ \\
\hline $\begin{array}{l}\text { Specific activity } \\
(\mu \mathrm{mol} / \mathrm{min} \text { per } \mathrm{mg})\end{array}$ & $9.6\left(30^{\circ} \mathrm{C}\right)^{11}$ & $31 \quad\left(25^{\circ} \mathrm{C}\right.$ & $26 \quad\left(25^{\circ} \mathrm{C}\right)$ & $30 \quad\left(30^{\circ} \mathrm{C}\right)^{12}$ & $40 \quad\left(35^{\circ} \mathrm{C}\right)^{1.3}$ \\
\hline
\end{tabular}

a All $K_{\mathrm{m}}$ values reported here were determined at air saturation. 
enzyme expressed in yeast (see Table I). After homogeneity was achieved the specific activity of the $E$. coli-derived enzyme was nearly the same as that observed for enzyme derived from yeast. Table II gives a comparison of the $K_{\mathrm{m}}$-values for glycolate and the specific activities of glycolate oxidases purified from various sources. The $K_{\mathrm{m}}$ values compiled in Table II are all in a narrow range (between 0.2 and $0.38 \mathrm{mM}$ ). With the exception of the value of the specific activity reported for glycolate oxidase isolated from spinach [11] the specific activities found for the recombinant spinach enzymes are similar to those found for the enzyme from pea leaves [12] and pumpkin cotyledons [13].

The ultraviolet-visible spectrum of recombinant GAO from both sources was identical (data not shown). Although these findings indicate that the enzymes expressed in $E$. coli and in yeast are identical, we were concerned about a recent report [14] that flavocytochrome $b_{2}$ is expressed in $E$. coli as a somewhat smaller protein lacking the first five $\mathrm{N}$-terminal amino acids. Since GAO is closely related to flavocytochrome $b_{2}$ (up to $40 \%$ sequence identity, Ref. 15) we found it important to make sure that no such truncation occurs with GAO. Furthermore, Söderlind and Lindqvist (personal communication) attempted to express GAO under the control of the $\lambda \mathrm{PL}$ promotor in $E$. coli but observed that a substantially smaller protein was produced. SDS gel electrophoretic comparison of GAO isolated from $E$. coli and yeast, respectively, did not reveal any differences in apparent molecular weight

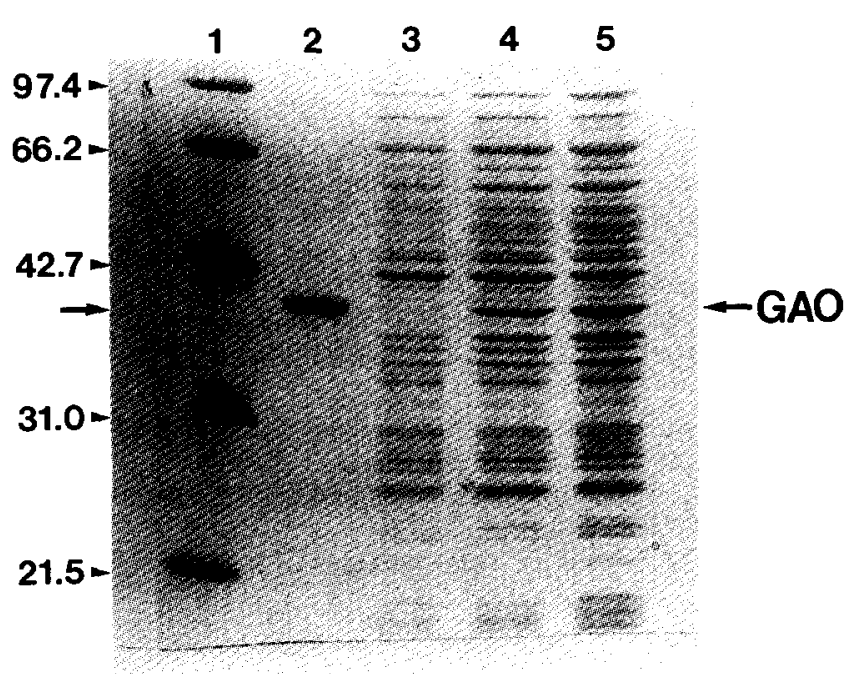

Fig. 3. Expression of spinach glycolate oxidase in E. coli strain BL 21 (DE 3). The SDS-gel electrophoresis shown in the figure demonstrates the expression of spinach glycolate oxidase in $E$. coli. The lanes contained the following samples: lane 1, standard proteins (molecular weights are given on the left); lane 2, purified spinach glycolate oxidase from $E$. coli; lane 3 , cell extract before induction with IPTG; lane 4 , cell extract $2 \mathrm{~h}$ after induction with IPTG and lane 5 , cell extract $4 \mathrm{~h}$ after induction with IPTG.
TABLE III

Expression of glycolate oxidase as a function of time

$1 \mathrm{I}$ TB medium containing $100 \mu \mathrm{g} / \mathrm{ml}$ ampicillin and $50 \mu \mathrm{g} / \mathrm{ml}$ chloramphenicol was inoculated with BL21 (DE3) carrying plasmids pLysS and pPM1. Expression of GAO was induced with IPTG (final concentration $400 \mu \mathrm{M}$ ) at an $\mathrm{OD}_{600}$ of 0.8 . At the times given below $100 \mathrm{ml}$ samples were taken and a crude extract was prepared as described in Materials and Methods. GAO activity was determined in the crude extract employing the enzyme coupled assay (see Materials and Methods) and the absorbance at $280 \mathrm{~nm}$ was used as a measure of protein concentration.

\begin{tabular}{ll}
\hline $\begin{array}{l}\text { Time } \\
\text { (h) }\end{array}$ & $\begin{array}{l}\text { Specific activity } \times 10^{-3} \\
\left(\Delta \mathrm{OD}_{440} \times \min ^{-1} / \mathrm{OD}_{280}\right)\end{array}$ \\
\hline 2 & 0.5 \\
4 & 0.9 \\
7 & 2.2 \\
10 & 2.6 \\
13 & 3.3 \\
19 & 3.6 \\
22 & 3.3 \\
\hline
\end{tabular}

but since small changes cannot be detected with that method we subjected a purified sample of GAO derived from $E$. coli to an $\mathrm{N}$-terminal protein sequence determination. The result showed that the first ten amino acids of GAO derived from $E$. coli matched the $\mathrm{N}$-terminal sequence determined for the spinach enzyme $[2,16]$. Black et al. [14] suggested that the expression of a truncated flavocytochrome $b_{2}$ is due to translation initiation at a putative Shine-Delgarno sequence that comprises the first amino acid of the mature protein. In contrast to the expression plasmid used for flavocytochrome $b_{2}$, pPM1 (see Fig. 2) provides an optimal Shine-Delgarno sequence with the right spacing to the ATG-starting codon of the GAO-gene, which probably prevents formation of fortuitous complexes between the mRNA of GAO and the 16S rRNA.

\section{Optimization of growth conditions}

Fig. 3 suggests that GAO might accumulate for more than $4 \mathrm{~h}$ after induction, as was also reported for other proteins [5]. In order to determine the optimal time of induction we measured the enzymatic activity over $22 \mathrm{~h}$ after addition of IPTG (final concentration $400 \mu \mathrm{M}$ ). The results are summarized in Table III. The enzyme activity increases steadily with the time of growth after induction with IPTG and reaches a maximum after approx. 18-20 h. This finding implies that the GAO is not toxic for the cells since plasmids which produce toxic gene products are eliminated readily within a few generations of bacterial growth. On the other hand the expression of GAO is low compared to other proteins which have been produced by this expression system to as much as $50 \%$ of the total soluble protein [17]. The reasons for this broad range of expression levels are still not fully understood. The possi- 
TABLE IV

Induction of glycolate oxidase expression as a function of cell density

Three flasks each with 1 I TB medium containing $100 \mu \mathrm{g} / \mathrm{ml}$ ampicillin and $50 \mu \mathrm{g} / \mathrm{ml}$ chloramphenicol were inoculated with BL21 (DE3) carrying plasmids pLysS and pPM1. At $\mathrm{OD}_{600}$ of $0.2,0.6$ and 1.0, respectively, expression of GAO was induced with IPTG (final concentration $400 \mu \mathrm{M}$ ). After 2 and $4 \mathrm{~h} 100 \mathrm{ml}$ samples were taken and crude extracts were prepared as described in Materials and Methods. GAO activity in the crude extract was determined with the enzyme coupled assay (see Materials and Methods) and the $\mathrm{OD}_{2 \times 10}$ was used as an estimate for protein concentration.

\begin{tabular}{llll}
\hline $\begin{array}{l}\text { Induction } \\
\text { at } \mathrm{OD}_{6+1+1}\end{array}$ & $\begin{array}{l}\text { Induction } \\
(\mathrm{h})\end{array}$ & $\begin{array}{l}\text { Activity } \\
(\Delta \mathrm{OD} \times \\
\left.\mathrm{min}^{-1}\right)\end{array}$ & $\begin{array}{l}\text { Specific activity } \times 10^{-3} \\
\left(\Delta \mathrm{OD} \times \mathrm{min}^{-3} / \mathrm{OD}_{2 \times 0}\right)\end{array}$ \\
\hline 0.2 & 2 & 0 & - \\
0.6 & 4 & 0 & - \\
& 2 & 0.024 & 0.42 \\
1.0 & 4 & 0.045 & 0.97 \\
& 2 & 0.170 & 3.2 \\
\hline
\end{tabular}

ble factors involved have been summarized recently [18].

Another factor which might affect the expression is the concentration of the inducer. Studier and coworkers [5] used $400 \mu \mathrm{M}$ IPTG in their protocol. Since IPTG is a rather costly component we decided to investigate the dependency of the expression system on the IPTG concentration. We found that in the range of 25 to $400 \mu \mathrm{M}$ final concentration of IPTG the expression level was independent of the inducer concentration.

In order to further optimize the conditions for expression we induced the bacterial cultures at various cell densities. After 2 and $4 \mathrm{~h}$ of induction, respectively, the activity and specific activity was measured. Induction of the culture at a low cell density $\left(\mathrm{OD}_{600}\right.$ of 0.2 ) completely failed to turn on the expression of GAO. At higher cell densities $\left(\mathrm{OD}_{600}=0.6\right.$ and 1.0) expression occurred and was highest at $\mathrm{OD}_{600}=1$. At the same time the specific activity was also optimal at $\mathrm{OD}_{600}=1$. A summary of this experiment is given in Table IV. After induction of a culture at $\mathrm{OD}_{600}=1$ and growth for $\sim 18-20 \mathrm{~h}$ (see above) GAO accounts for $\sim 1 \%$ of the soluble protein.

In comparison with the expression of $\mathrm{GAO}$ as a $\beta$-galactosidase fusion protein and the expression with the heat inducible $\lambda$ PL promotor the yield achieved here was considerably lower. However, in contrast, the newly constructed expression plasmid pPM1 provides soluble and active GAO in amounts sufficient for further physicochemical and rapid reaction investigations of wild-type and mutant glycolate oxidases.

\section{Acknowledgements}

This work was supported by grants from the United States Health Service GM-11106 to V.M., GM-21444 to C.H.W. and by the Health Services and Research Administration of the Department of Veteran Affairs. We would like to thank Dennis J. Thiele and Kazuyo Saito for their advice in developing a suitable cloning strategy and their help in the initial stages of the experiments.

\section{References}

1 Lindquist, Y. and Brandén. C.-I. (1989) J. Biol. Chem. 264. 3624-3628.

2 Volokita, M. and Somerville, C.R. (1987) J. Biol. Chem. 262, $15825-15828$.

3 Marston, F.A.O. (1986) Biochem. J. 240. 1-12.

4 Macheroux, P., Massey, V., Thiele, D.J. and Volokita, M. (1991) Biochemistry 30, 4612-4619.

5 Studier, F.W., Rosenberg, A.H., Dunn, J.J. and Dubendorff, J.W. (1990) Methods Enzymol. 185, 60-89.

6 Sambrook, J., Fritsch, E.F. and Maniatis. T. (1989) Molecular Cloning: A Laboratory Manual, 2nd Edn., Cold Spring Harbor Laboratory, Gold Spring Harbor.

7 Arraj, J.A. and Marinus, M.G. (1983) J. Bacteriol. 153, 562-565.

8 Bullock, W.D., Fernandez, J.M. and Short, J.M. (1987) Biotechniques 5,376 .

9 Bowden, G.A., Parredes, A.M. and Georgiou, G. (1991) Bio/ Technology 9, 725-730.

10) Zelitch, I. and Ochoa, S. (1953) J. Biol. Chem. 201, 707-718.

11 Frigerio, N.A. and Harbury, H.A. (1958) J. Biol. Chem. 231, $135-157$.

12 Kerr, M.W. and Groves, D. (1975) Phytochemistry 14, 359-362.

13 Nishimura, M., Akhmedov, Y.D., Strazalka, K. and Akazawa, T. (1983) Arch. Biochem. Biophys. 222, 397-402.

14 Black, T.M., White, S.A., Reid, G.A. and Chapman, S.K. (1989) Biochem. J. 258, 255-259.

15 Lederer, F. (1991) in Chemistry and Biochemistry of Flavoenzymes (Müller, F., ed.), Vol. II, pp. 153-242, CRC Press, Boca Raton.

16 Cederlund, E., Lindqvist, Y. Söderlund, G., Brändén, C.-I. and Jörnvall, H. (1988) Eur. J. Biochem. 173, 523-530.

17 Ilag, L.L., Jahn, D., Eggertson, G. and Söll, D. (1991) J. Bacteriol. 173, 3408-3413.

18 Balbas, P. and Bolivar, F. (1990) Methods Enzymol. 185, 14-37. 